\title{
Multifaceted glycoadjuvant@AuNPs inhibits tumor metastasis through promoting T cell activation and remodeling tumor microenvironment
}

Xiaojing X $\mathrm{u}^{1 \dagger}$, Minfeng Gan ${ }^{2 \dagger}$, Youzhen $\mathrm{Ge}^{1,3 \dagger}$, Cheng Yi ${ }^{1,3}$, Tianyun Feng ${ }^{1,3}$, Mengjie Liu ${ }^{4}$, Cenhao Wu ${ }^{2}$, Xiang Chen ${ }^{5}$, Weidong Zhang ${ }^{4^{*}}$, Lixiang Zhao ${ }^{1 *}$ and Jun Zou ${ }^{2^{*}}$ (D)

\begin{abstract}
Abstarct
Background: Cytosine-phosphate-guanine $(\mathrm{CpG})$ dinucleotides has been used as adjuvants for cancer immunotherapy. However, unmodified $\mathrm{CpG}$ are not very efficient in clinical trials. Glucose, ligand of C-type lectin receptors (CLRs), can promote DC maturation and antigen presentation, which is the first step of induction of adaptive immune responses. Therefore, conjugation of type B CpG DNA to glucose-containing glycopolymers may enhance the therapeutic effects against tumor by CpG-based vaccine.

Methods: gCpG was developed by chemical conjugation of type B CpG DNA to glucose-containing glycopolymers. The therapeutic effects of $\mathrm{gCpG}$-based vaccine were tested in both murine primary melanoma model and its metastasis model.

Results: $\mathrm{gCpG}$ based tumor vaccine inhibited both primary and metastasis of melanoma in mice which was dependent on CD8 + T cells and IFNy. In tumor microenvironment, gCpG treatment increased Th1 and CTL infiltration, increased M1 macrophages, decreased Tregs and MDSCs populations, and promoted inflammatory milieu with enhanced secretion of IFNy and TNFa. The anti-tumor efficacy of $\mathrm{gCpG}$ was dramatically enhanced when combined with anti-PD1 immunotherapy.
\end{abstract}

Conclusions: We confirmed that $\mathrm{gCpG}$ was a promising adjuvant for vaccine formulation by activating both tumorspecific Th1 and Tc1 responses, and regulating tumor microenvironments.

\footnotetext{
*Correspondence: zhangweidong@suda.edu.cn; zhaolixiang@suda.edu.cn; jzou@suda.edu.cn

${ }^{\dagger}$ Xiaojing Xu, Minfeng Gan and Youzhen Ge authors contributed equally

${ }^{1}$ College of Basic Medicine and Biological Sciences, Medical Department,

Soochow University, 215123 Suzhou, People's Republic of China

2 Department of Orthopaedic Surgery, The First Affiliated Hospital

of Soochow University, Suzhou 215006, Jiangsu, China

${ }^{4}$ Center for Soft Condensed Matter Physics and Interdisciplinary

Research, Soochow University, Suzhou 215006, People's Republic of China

Full list of author information is available at the end of the article
}

(c) The Author(s) 2021. Open Access This article is licensed under a Creative Commons Attribution 4.0 International License, which permits use, sharing, adaptation, distribution and reproduction in any medium or format, as long as you give appropriate credit to the original author(s) and the source, provide a link to the Creative Commons licence, and indicate if changes were made. The images or other third party material in this article are included in the article's Creative Commons licence, unless indicated otherwise in a credit line to the material. If material is not included in the article's Creative Commons licence and your intended use is not permitted by statutory regulation or exceeds the permitted use, you will need to obtain permission directly from the copyright holder. To view a copy of this licence, visit http://creativecommons.org/licenses/by/4.0/. The Creative Commons Public Domain Dedication waiver (http://creativeco mmons.org/publicdomain/zero/1.0/) applies to the data made available in this article, unless otherwise stated in a credit line to the data. 


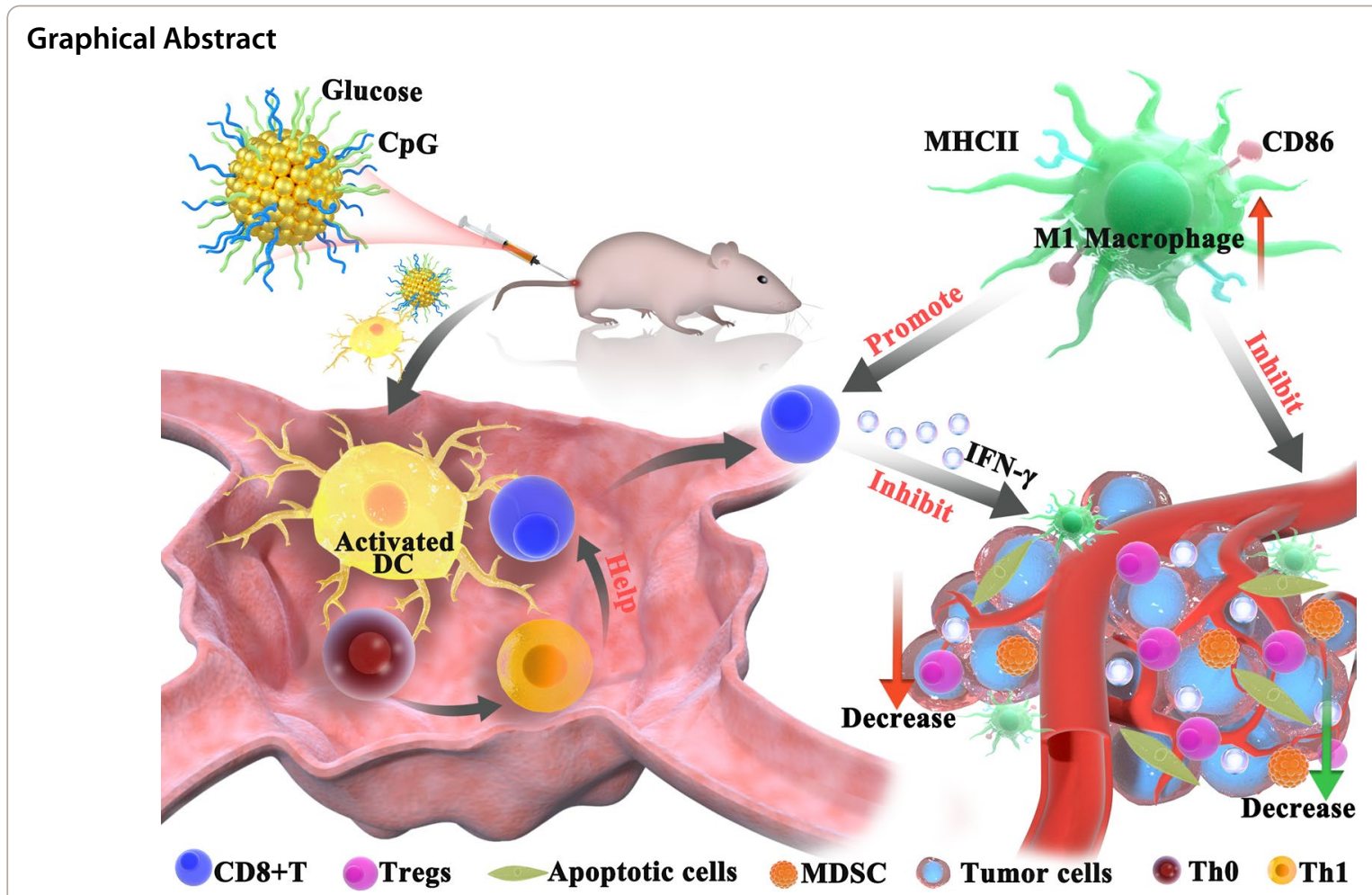

\section{Background}

Cytotoxic T lymphocyte (CTL) is a key player of antitumor immune response [1-3]. Toll-like receptor (TLR) agonists have been widely tested as vaccine adjuvants, since they can stimulate innate immune response, followed by adaptive immune response [4]. Unmethylated CpG, agonist of TLR9, activates type I immunity and has been widely used as adjuvant to stimulate CTLs. However, unmodified CpG-based tumor vaccines are not very efficient in clinical trials [10]. The main reasons of the failure of unmodified CpG-based tumor vaccines are those: (1) unmodified CpG stimulates relatively weak CTL response in vivo, and (2) in tumor microenvironment (TME), CTL is always inhibited by immune suppressive cells, including tumor-associated macrophages (TAMs), regulatory $\mathrm{T}$ cells (Tregs) and myeloid-derived suppressor cells (MDSCs) [11-13].

Carbohydrates play the most important role in living bodies because which can be used as food for energy sources, and as ligand for selectively binding with protein through recognition of C-type lectin receptors (CLRs) $[14,15]$. CLRs signal is important for antigen presentation on DCs maturation, which further induce adaptive immunity. For instance, the high level of glucose can promote DCs maturation [16]. On the contrary, lack of glucose dampens antitumor activities of tumor-infiltrating
$\mathrm{T}$ cells in tumor microenvironment [17]. Therefore, CLR-targeted (glucose) and TLR9-targeted (CpG) glycopolymer-based adjuvant may have powerful therapeutic effects against cancer.

In present study, glycoadjuvant@AuNPs (gCpG) were obtained by conjugating $\mathrm{CpG}$ to glucose-containing glycopolymers [18], and the therapeutic effects of gCpG-based tumor vaccine were tested on melanoma metastasis model. We found that $\mathrm{gCpG}$ based tumor vaccine controlled both primary tumor and its metastasis. It promoted DC maturation, enhanced the antigen-specific CTL response and regulated tumor microenvironments by decreasing Tregs and MDSCs, and promoting polarization towards M1 macrophages, which may be used for cancer vaccine formulation.

\section{Materials and methods} Glycoadjuvant@AuNPs (gCpG) preparation The glycoadjuvant@AuNPs (gCpG) could be obtained using our reported method. First, glycopolymer could be successfully prepared by photo-induced reversible addition fragmentation chain transfer (RAFT) polymerization using 2-cyanoprop-2-yl- $\alpha$-dithionaphthalate (CPDN) as RAFT agent, 2-(methacrylamido) glucopyranose (MAG), and N-3,4-dihydroxybenzenethyl methacrylamide (DMA) as monomer. Then, the catechol-containing 
glycopolymer was employed to prepare glycoadjuvant@ AuNPs in one pot, where catechol-containing glycopolymer, $\mathrm{HAuCl}_{4}$, and amine-functionalized CpG (CpG-NH $\left.\mathrm{N}_{2}\right)$ could react in a single step to form adjuvant.

\section{In vitro experiments Cell lines}

B16-OVA cells were obtained from ATCC and maintained in complete DMEM medium (Gibco) with $10 \%$ fetal bovine serum.

\section{Immune cell preparation}

The homogenate of spleens and tumor tissues were filtered through 70-mm nylon meshes, and single-cell suspensions of the immune cells were obtained after separation on a Percoll gradient of $40 \%$ density. EasySep ${ }^{\text {TM }}$ Mouse $\mathrm{CD}^{+} \mathrm{T}$ Cell Isolation Kit (Stemcell) was used to isolate $\mathrm{CD}^{+} \mathrm{T}$ cells from splenocytes.

\section{Proliferation assay of T cells}

After $24 \mathrm{~h}$ co-culturing with OVA protein, splenocytes were irradiated with 200 Gy via a ${ }^{60} \mathrm{Go}$ source, and used as stimulatory cells. Stimulatory cells were added to $5.5 \times 10^{3} \mathrm{CD}^{+}$or $5 \times 10^{3} \mathrm{CD}^{+} \mathrm{T}$ cells. After about $64 \mathrm{~h}$ co-culture, CCK 8 was added to the co-cultured system in a final concentration of $10 \%$. After $2 \mathrm{~h}$ incubation, OD450 values were detected and used for the counting of stimulation index (SI). The following forma were used to calculate SI: (OD450 values of T cells co-cultured with OVA pulsed stimulatory cells - OD450 values of media control)/(OD450 values of T cells co-cultured with unstimulated splenocyte - OD450 values of media control).

\section{Tumor-killing assay}

Effectors in this assay were $\mathrm{CD}^{+} \mathrm{T}$ or splenocytes without $\mathrm{CD}^{+} \mathrm{T}$ cells. Targets $\left(4 \times 10^{3} \mathrm{~B} 16\right.$-OVA $)$ were plated and incubated for $2 \mathrm{~h}$ in 96-well plate. Then effectors were added to and co-cultured with targets at different ratios. Tumor-killing was detected by using CytoTox $96^{\circledR}$ Non-Radioactive Cytotoxicity Assay purchased from Promega. The percentages of tumor-killing were calculated: (experimental - targets spontaneous-effectors spontaneous $) \times 100 /($ targets maximum - targets spontaneous $)$.

\section{Bone marrow DC (BMDC) generation}

BMDC were collected from the femur and tibia of mice and cultured in RPMI 1640 medium supplemented with GM-CSF (10 ng/mL), IL-4 (10 ng/mL) and FCS (10\%). The medium was half-replaced every 2 days, and BMDCs were harvested after 7 days.

\section{Flow cytometry assay}

The following monoclonal antibodies (BD Biosciences and Biolegend) were used: FITC-anti CD4 (RM4-5), FITC-anti NK1.1 (PK136), FITC-anti CD19 (1D3), FITCanti CD62L (MEL-14), FITC-anti MHC II (M5), FITCanti F4/80 (BM8), PE-antiCD3e (145-2C11), PE-anti IL4 (11B11), PE-anti IFNy (XMG1.2), PE-anti CD206 (C068C2), PE-anti Gr1 (RB6-8C5), PE-anti CD44 (IM7), PE-anti CD16/32 (93), PerCP Cy5.5-anti CD8a (53-6.7), PerCP Cy5.5-anti Gr1 (RB6-8C5), PE-Cy7-anti CD11b (M1/70), PE-Cy7-anti CD11c (HL3), APC-anti CD45 (30F11), APC-anti Foxp3 (150D), APC-anti PD1 (29F.1A12) and APC-anti TNF $\alpha$ (MP6-XT22). Single-cell suspensions was staining at $4{ }^{\circ} \mathrm{C}$ with antibodies in PBS supplemented with $1 \% \mathrm{BSA}, 0.1 \% \mathrm{NaN}_{3}, 0.2 \mathrm{mM}$ EDTA and Fc-blocker for about $30 \mathrm{~min}$. The results were analyzed with FACS CantoII (BD Biosciences) using CellQuest software.

\section{OVA-specific $\mathrm{CD}^{+} T$ staining assay}

TILs were stained with OVA-specific tetramers (Beckman Coulter), Fc-blocker and APC-anti CD8 at room temperature. 30 min later, TILs were washed and resuspended in PBS supplemented with 1\% BSA, 0.1\% $\mathrm{NaN}_{3}$ and $0.2 \mathrm{mM}$ EDTA, and analyzed with FACS CantoII (BD Biosciences).

\section{In vivo experiments \\ Murine melanoma therapeutic models}

Animal experiments were approved by the Animal Experiment Ethics Committee of Soochow University, and performed under specific-pathogen-free (SPF) conditions. 6-week-old SPF female C57BL/6 mice were purchased from the Shanghai Laboratory Animal Center (Shanghai, China). Animals were euthanized in a $\mathrm{CO}_{2}-$ containing chamber, at the end of each experiment.

Primary melanoma models were generated by s.c. injection of $2.5 \times 10^{5}$ B16-OVA cells into the left flank of the animal. At day 7, vaccines were s.c. immunized at the right flank, and the immunization was repeated at day 12 . From day 9, the longest dimension (L) and the shortest dimension (width, $\mathrm{W}$ ) of the tumors were daily measured. Tumor volume were calculated by $\mathrm{L} \times \mathrm{W}^{2} / 2$.

Metastasis models were generated by i.v. injection of $9 \times 10^{5}$ B16-OVA from tail vein of each mouse. At day 7 and 12, vaccines were s.c. immunized at the right flank, respectively. Animals were sacrificed at day 19, and the lung metastatic nodules were counted.

\section{Immunohistochemistry and histopathology}

Paraffin tumor sections were sequentially deparaffinized. After overnight incubation with anti-CD4 (GK1.5, 
Abcam) or anti-CD8 (2.43, Abcam) antibodies, HRPconjugated rabbit anti-rat IgG antibodies were added. After nuclear counter-staining with hematoxylin (Solarbio), the presences of $\mathrm{CD} 4$ or $\mathrm{CD} 8$ protein were visualized by DAB staining.

\section{Adoptive transferring $\mathrm{CD} 8^{+} T$ cells}

Mouse was inoculated with $9 \times 10^{5}$ B16-OVA cells from tail vein, and splenic $\mathrm{CD} 8^{+} \mathrm{T}$ cells were separated 7 days later. About $4 \times 10^{6}$ isolated $\mathrm{CD} 8^{+} \mathrm{T}$ cells were injected i.v. into mice with metastasis. The lung metastatic nodules were examined 12 days later.

\section{In vivo cell depletion}

Antibody specific to mouse CD4 (GK1.5), CD8 (53-6.7), Gr1 (RB6-8C5) and IFN- $\gamma$ (XMG1.2) purchased from Bioxcell were used to deplete $\mathrm{CD} 4^{+}, \mathrm{CD}^{+}$cells, MDSC, and neutralize IFN- $\gamma$, respectively. Mouse was i.p. injected with appropriate antibodies (200 $\mu$ g per dose) 1 day before vaccines immunization, and the antibodies with the same dose were repeatedly inoculated 7 days later. Clophosome (Anionic Liposomal Clodronate, FormuMax) was used to deplete macrophages by i.p. injection of $800 \mu \mathrm{g} 2$ days before and 5 days after the first vaccination. The efficacy of cell depletion was confirmed by flow cytometric analysis.

\section{Statistical analysis}

Each experiment was triplicate performed. Data were expressed as mean \pm standard deviation (SD). The statistically significant difference between groups was evaluated by GraphPad Prism 8 software for Windows (GraphPad Software, San Diego, CA). $p<0.05$ was considered to be a significant difference. The significance levels are marked ${ }^{*} p<0.05,{ }^{* * *} p<0.01,{ }^{* * * * *} p<0.001$ and ${ }^{* * * * * *} p<0.0001$.

\section{Results}

gCpG inhibits tumor growth and promotes $\mathrm{T}$ cell responses in primary melanoma

gCpG can enhance the expression of secreted embryonic alkaline phosphatase (SEAP) by macrophages [18], indicating that glycopolymer-modification can improve the CpG's immune stimulatory activity. To examine the effects of gCpG on DC maturation, BMDCs were cocultured with PBS, CpG $(2 \mu \mathrm{g} / \mathrm{mL})$ or gCpG $(2 \mu \mathrm{g} / \mathrm{mL})$, and the surface markers (CD86 and MHC II) were examined by FACs. The results showed that $\mathrm{gCpG}$ promoted BMDC maturation by upregulating expression of MHC II and CD86 molecules (Fig. 1a and b).

To determine the therapeutic effects of gCpG againt primary tumor, mice bearing primary melanoma were immunized with each vaccine, respectively. gCpG + OVA treatment effectively controlled tumor growth (Fig. 1c), whereas CpG+OVA treatment only slightly inhibited tumor growth.

Cell populations in tumor were examined on day 19 post tumor injection using flow cytometry. gCpG + OVA treatment increased the $\mathrm{CD}^{+} \mathrm{T}$ prevalence in tumor sites (Fig. 1d). Tetramer staining assay further revealed that gCpG+OVA treatment significantly enhanced OVA-specific $\mathrm{CD}^{+} \mathrm{T}$ cells infiltrating into tumor site (Fig. 1e). gCpG + OVA treatment greatly enhanced $\mathrm{CD}^{+} \mathrm{T}$ killing capacity against B16-OVA cells (Fig. 1f), while had no obvious effects on other populations killing capacity (Fig. 1g). Together, above results revealed that gCpG based tumor vaccine could inhibit primary melanoma and promote $\mathrm{CD} 8^{+} \mathrm{T}$ cell responses.

\section{gCpG inhibits lung metastasis of melanoma and promotes T cell responses}

Metastasis is considered to be the leading cause of death for patients with cancer. Therefore, we wondered if gCpG included vaccine may also control melanoma metastasis. Animals were i.v. inoculated with B16-OVA, and vaccines were given at 7- and 12-days post tumor injection. gCpG + OVA significantly reduced the metastatic nodes of melanoma in lung (Fig. 2a), while CpG + OVA only exhibited slightly inhibition of tumor metastases.

To examine possible mechanisms of therapeutic efficacy of gCpG included vaccine, splenocytes and TILs were analyzed. gCpG + OVA treatment didn't significantly change the total numbers of splenocytes (Fig. 2b). $\mathrm{CD}^{+} \mathrm{T}$ prevalence and total numbers were significantly increased in spleen after gCpG + OVA treatment (Fig. 2c and d). Although the percentages of $\mathrm{CD}^{+} \mathrm{T}$ cells were similar in spleen among each group, the $\mathrm{CD} 4^{+} \mathrm{T}$ numbers were significantly increased after CpG + OVA treatment (Fig. 2e and $\mathrm{f}$ ).

After gCpG + OVA treatment, tumoral infiltration of $\mathrm{CD}^{+} \mathrm{T}$ was significantly increased $(p<0.01$, Fig. $2 \mathrm{~g})$. gCpG + OVA treatment also significantly increased $\mathrm{CD}^{+}{ }^{+}$infiltration, as compared with $\mathrm{PBS}$ treatment (Fig. 2h). $\mathrm{CD}^{+}$and $\mathrm{CD} 4^{+} \mathrm{T}$ cells infiltrations in tumor sites were also confirmed by IHC (Fig. 2i).

\section{gCpG promotes antigen-specific Th1 cytokines secretion by both $\mathrm{CD}^{+}$and $\mathrm{CD}^{+} \mathrm{T}$ cells}

Intracellular staining was used to examine the antigen-specific T-cell in melanoma metastasis model. gCpG + OVA treatment significantly enhanced the percentage and total numbers of $\mathrm{IFN}^{+} \mathrm{CD}^{+} \mathrm{T}$ in spleen, compared to PBS treatment $(p<0.0001$, Fig. 3A). Although different treatments didn't significantly change the percentage of IFN $\gamma$-producing $\mathrm{CD}^{+} \mathrm{T}$ cells in spleen, 
a

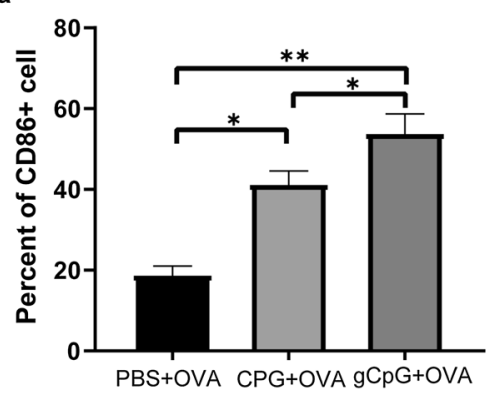

C

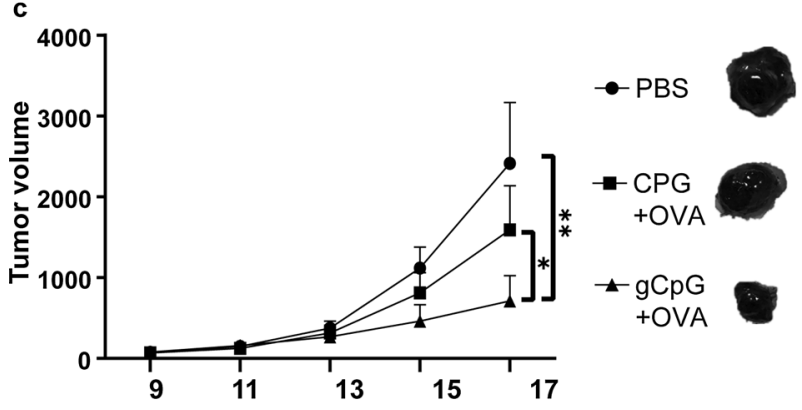

e

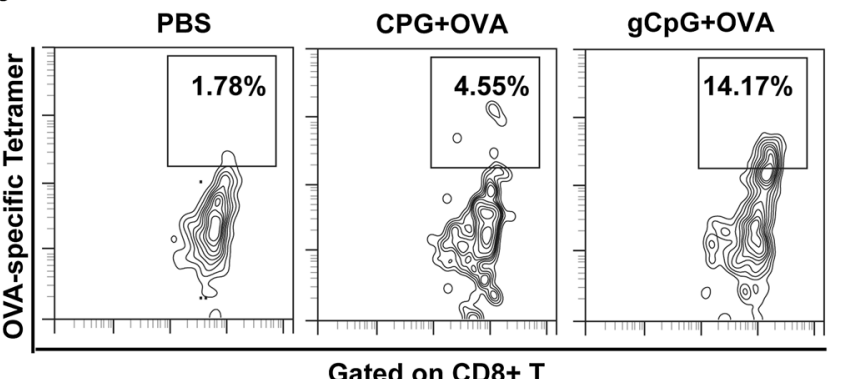

Gated on CD8+ T

f

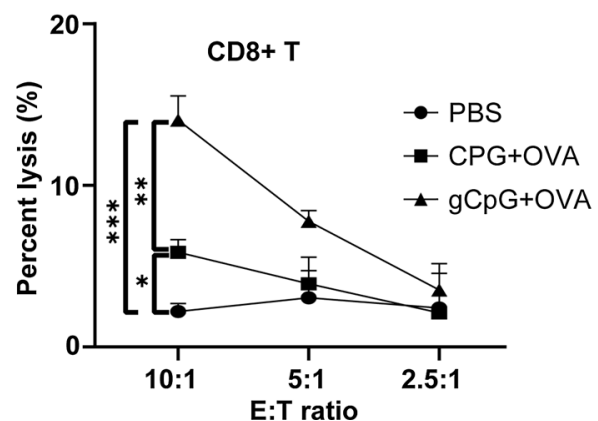

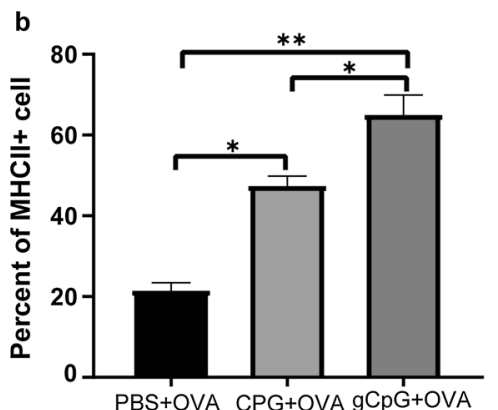

d

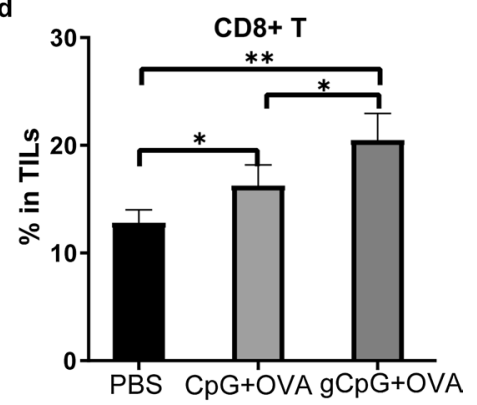

OVA-specific Tetramer

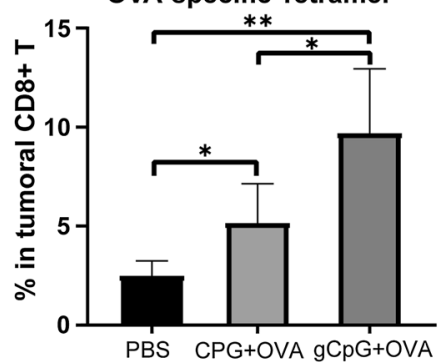

g

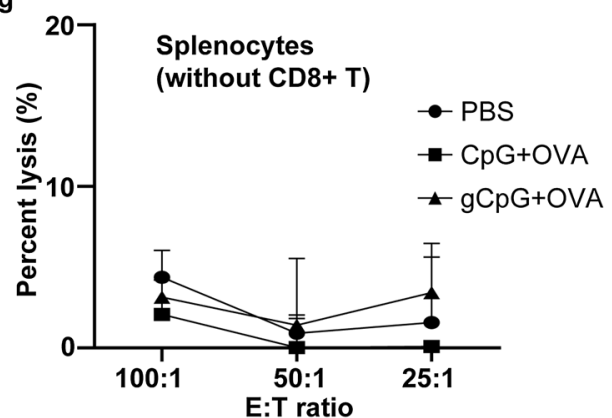

Fig. $1 \mathrm{gCpG}$ inhibits tumor growth and promotes T cell responses in primary tumor model. The levels of CD86 (a) and MHC II (b) expression on BMDC were measured by flow cytometry. c Tumor growth of melanoma-bearing mice. Mice were injected with $2 \times 10^{5}$ B16-OVA cells, and immunized s.c. with one of the three tumor vaccines at the left flank on day 7 and 12 post tumor inoculation, respectively. $\mathbf{d}$ Mice were sacrificed on day 19 after tumor inoculation. Percentage of tumor-infiltrating CD ${ }^{+}$T cells were analyzed by flow cytometry. e Tetramer staining of OVAspecific CD8 ${ }^{+}$T cells in TILs. Cytotoxicity assay of splenic CD8 ${ }^{+}$T cells $(\mathbf{f})$ and other population without CD8 ${ }^{+}$T cells $(\mathbf{g})$ from the tumor-bearing mice against B16-OVA tumor cells. The specific killings were determined using CytoTox 96 nonradioactive cytotoxicity assay. The data shown are the representative of at least three experiments. ${ }^{*} p<0.05$ and ${ }^{* *} p<0.01,{ }^{* * *} p<0.001$ and ${ }^{* * *} p<0.0001$ 


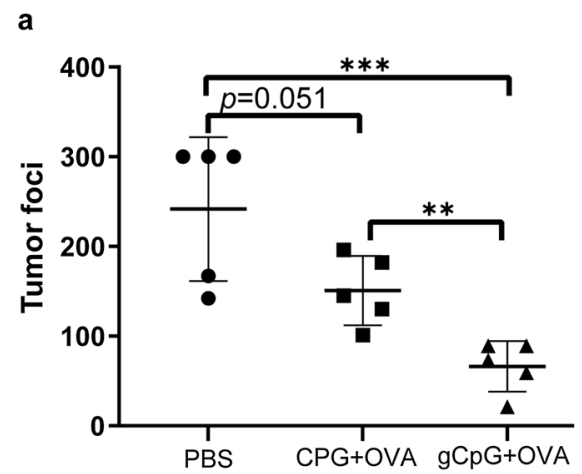

C

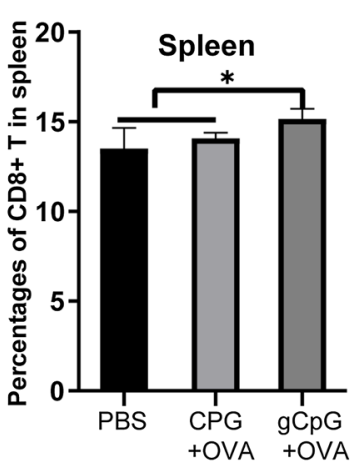

g
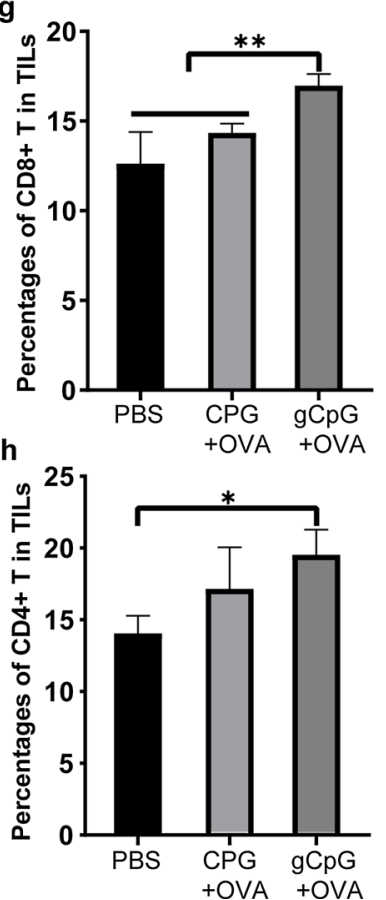

CD4

CD8 d

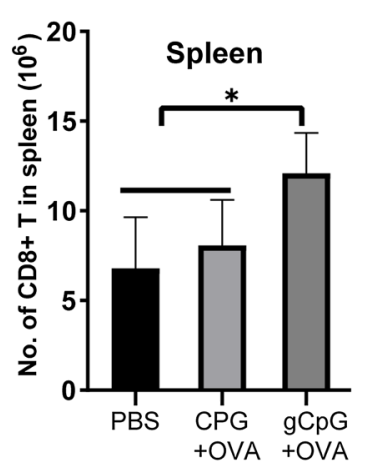

PBS

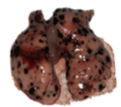

CpG+OVA

gCpG+OVA
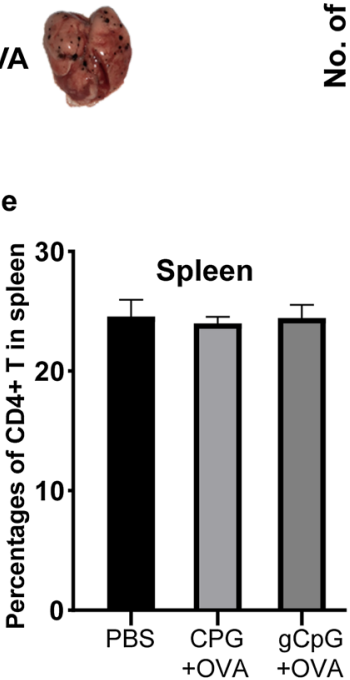

b

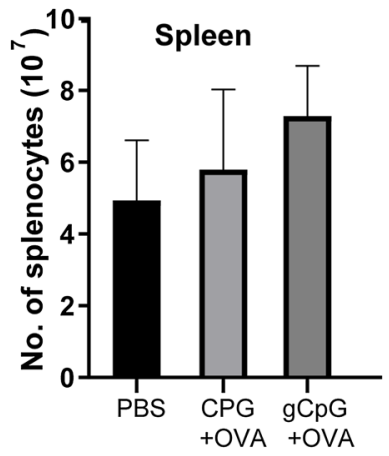

f

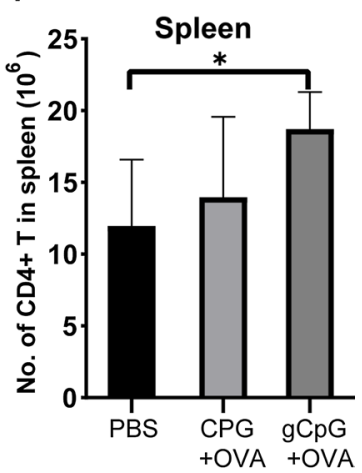

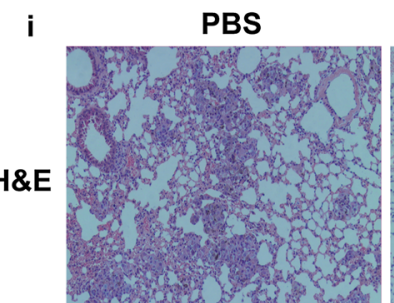

CpG+OVA

gCpG+OVA
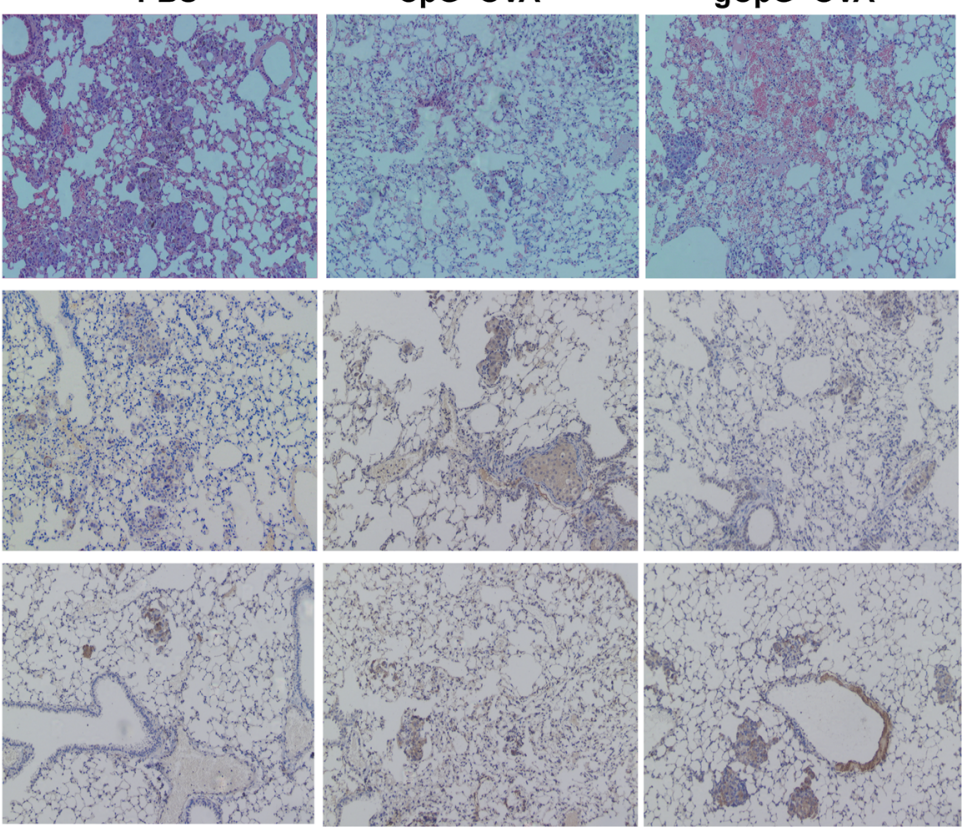

Fig. $2 \mathrm{gCpG}$ inhibits lung metastasis of melanoma. a The numbers of metastatic nodules in the lungs of the tumor-bearing mice. Mice were injected i.v. with $8 \times 10^{5}$ B16-OVA from tail vein. At day 7 and 12 post tumor inoculation, mice were immunized with different vaccines. Seven days later, mice were sacrificed, and the metastatic nodules in lungs were quantified. Total cell numbers of splenocytes (b), frequencies and total cell numbers of $\mathrm{CD} 8^{+} \mathrm{T}(\mathbf{c}$ and $\mathbf{d})$, and $\mathrm{CD} 4^{+} \mathrm{T}(\mathbf{e}$ and $\mathbf{f})$ cells in the spleen and frequencies of tumor-infiltrating $\mathrm{CD} 8^{+} \mathrm{T}(\mathbf{g})$ and $\mathrm{CD} 4^{+} \mathrm{T}$ cells $(\mathbf{h})$ were analyzed by flow cytometry. $\mathbf{i}$ H\&E and immunochemical staining for $C D 4^{+}$and $C D 8^{+} T$ cells of tumor tissues from melanoma-bearing mice (200 $\times$ magnification). The assays were done in quadruplicates. The data shown are the representative of at least three experiments. ${ }^{*} p<0.05$ and ${ }^{* *} p<0.01,{ }^{* *} p<0.001$ and ${ }^{* * *} p<0.0001$ 
gCpG + OVA treatment significantly increased the total cell numbers of this population $(p<0.05$, Fig. 3a). The total numbers of $\mathrm{TNF} \alpha^{+} \mathrm{CD}^{+}{ }^{+}$cells and $\mathrm{TNF} \alpha^{+} \mathrm{CD} 4^{+}$ $\mathrm{T}$ cells in spleen were also increased after gCpG + OVA treatment (Fig. 3b).

In TILs, gCpG + OVA treatment significantly enhanced IFN $\gamma(p<0.0001$, Fig. 3c) and TNF $\alpha(p<0.05$, Fig. 3d $)$ production in tumoral infiltrating $\mathrm{CD}^{+} \mathrm{T}$ cells. Besides, CpG + OVA also significantly enhanced the percentages of $\mathrm{IFN}^{+} \mathrm{CD}^{+}$and $\mathrm{TNF} \alpha^{+} \mathrm{CD} 4^{+} \mathrm{T}$, as compared with PBS treatment (Fig. 3c and d). These results indicated that gCpG + OVA promoted both Tc1 and Th1 responses in metastatic melanoma model.

\section{gCpG promotes antigen-specific CTL response}

$\mathrm{CD}^{+} \mathrm{T}$ is one of most powerful effector cells of antitumor immune responses. First, we detected tumor specific $\mathrm{CD}^{+} \mathrm{T}$ population by tetramer staining assay, and the results showed that $\mathrm{gCpG}+\mathrm{OVA}$ treatment significantly increased tumoral infiltration of OVAspecific $\mathrm{CD}^{+} \mathrm{T}$ (Fig. 4a). gCpG + OVA treatment also greatly enhanced the proliferation of $\mathrm{CD}^{+} \mathrm{T}(p<0.0001$, Fig. $4 \mathrm{~b}$ ), while vaccine treatments didn't promote the proliferation of $\mathrm{CD}^{+}{ }^{+} \mathrm{T}$ cell (Fig. 4c). gCpG + OVA also dramatically enhanced $\mathrm{CD}^{+} \mathrm{T}$ killing capacity $(p<0.00001$, Fig. 4f), while splenocytes excluded with $\mathrm{CD}^{+} \mathrm{T}$ couldn't kill tumor cells directly (Fig. $4 \mathrm{~d}$ and e). These data indicated that gCpG + OVA promoted functions of antigen-specific $\mathrm{CD} 8^{+} \mathrm{T}$ cell.

\section{Antigen-specific $\mathrm{CD}^{+} \mathrm{T}$ and IFN $\gamma$ are critical for $\mathrm{gCpG}$ treatment}

Th1 and CTL cells are important effectors cells for antitumor response and we observed the strong activation of both Th1 and CTL upon gCpG+ OVA treatment. In order to examine which cell type plays the critical role in the anti-tumor response, $\mathrm{CD} 4^{+}$and $\mathrm{CD}^{+} \mathrm{T}$ cells were depleted by specific antibodies in metastasis model, respectively. Anti-tumor effects of gCpG based vaccine were partially reduced as the lack of $\mathrm{CD} 4^{+} \mathrm{T}$ cells, while depletion of $\mathrm{CD}^{+} \mathrm{T}$ abrogated the anti-tumor efficacy of the vaccine (Fig. 5a), indicating that gCpG based vaccine controlled tumor growth by $\mathrm{CD}^{+} \mathrm{T}$ cells. Adoptive transferring $\mathrm{CD}^{+} \mathrm{T}$ cells from mice treated with gCpG + OVA inhibited melanoma metastasis, on the contrary $\mathrm{CD}^{+} \mathrm{T}$ from $\mathrm{PBS}$ treated group had no therapeutic effects (Fig. 5b), confirmed the critical role of $\mathrm{CD}^{+} \mathrm{T}$ in controlling tumor metastasis by gCpG $+\mathrm{OVA}$. IFN- $\gamma$ is a key molecule produced by effector $\mathrm{CD} 8^{+} \mathrm{T}$ cells. IFN- $\gamma$ neutralization almost abrogated gCpG efficacy, indicated that the therapeutic effects of gCpG depended on IFN- $\gamma$ derived from antigen-specific $\mathrm{CD} 8^{+} \mathrm{T}$ (Fig. 5a).

To examine whether the gCpG+ OVA induced $\mathrm{CD} 8^{+}$ $\mathrm{T}$ response was limited against OVA, mice with B16F10 metastasis were adoptively transferred with $\mathrm{CD} 8^{+} \mathrm{T}$ cells isolated from mice treated with gCpG+OVA. The results showed that $\mathrm{CD} 8^{+} \mathrm{T}$ cells from mice treated with gCpG + OVA couldn't inhibit B16-F10 melanoma, indicated that gCpG $+\mathrm{OVA}$ induced $\mathrm{CD}^{+} \mathrm{T}$ cell response was OVA-specific (Fig. 5c).

\section{gCpG regulates tumor microenvironment}

$\mathrm{T}$ cell function can be dampened by immunosuppressive cell populations existing in tumor microenvironment such as Tregs, TAMs and MDSCs. In present study, gCpG + OVA treatment significantly decreased the percentages of Tregs (Fig. 6a), combined with increased $\mathrm{CD} 8^{+} \mathrm{T}$ population, which dramatically increased $\mathrm{CD} 8^{+}$ $\mathrm{T} /$ Treg ratio in gCpG + OVA treated mice (Fig. 6b).

TAMs contained two phenotypes, the M1 phenotype $\left(\mathrm{CD}^{2} 6^{+} \mathrm{MHCII}^{+}\right)$and $\mathrm{M} 2$ phenotype $\left(\mathrm{CD} 206^{+}\right)$. The former phenotype promotes anti-tumor responses, while the later exerts immunosuppressive functions. gCpG + OVA treatment significantly increased M1 TAMs in TME (Fig. 6c), but had no effects on M2 TAMs (Fig. 6d). MDSCs are very potent suppressors of cytotoxic T-cell immunity. gCpG + OVA treatment dramatically decreased the infiltration of $\mathrm{Gr} 1^{+} \mathrm{CD} 11 \mathrm{~b}^{+}$MDSCs (Fig. 6e). IFNY and TNF $\alpha$ (Th1 cytokine) expressions in TME were also determined by ELISA. Consistent with FACs results, gCpG treatment significantly increased IFN $\gamma$ and TNF $\alpha$ level in TME (Fig. 6f and g), suggesting gCpG promoted inflammatory milieu in TME.

To define the role of TAMs in the progress of tumor, Clophosome was used to deplete macrophages in vivo. Depletion of TAMs significantly promoted melanoma metastasis in gCpG + OVA group, while only slightly promoted tumor metastasis in PBS group (Fig. 6h), which might be a result of high percentage of M1 TAMs infiltration in gCpG + OVA treated group.

MDSCs depletion enhanced therapeutic effects of CpG based tumor vaccine greatly, as the high proportion of MDSCs infiltration in this group. However, MDSCs depletion only slightly enhanced the therapeutic effects

(See figure on next page.)

Fig. $3 \mathrm{gCpG}$ promotes tumor specific Th1 cytokines production on $\mathrm{CD} 4^{+}$and $\mathrm{CD} 8^{+} \mathrm{T}$ cells. a Intracellular staining of IFNy production on $\mathrm{CD} 8^{+}$ and $C D 4^{+} \mathrm{T}$ cells from splenocytes stimulated with OVA. $\mathbf{b}$ Intracellular staining of TNFa expression on $\mathrm{CD}^{+}$and $\mathrm{CD} 4^{+} \mathrm{T}$ cells from splenocytes stimulated with OVA. c Intracellular staining of IFNy production on $\mathrm{CD}^{+}$and CD4 ${ }^{+} \mathrm{T}$ cells from TILs stimulated with OVA. $\mathbf{d}$ Intracellular staining of TNFa expression on $\mathrm{CD}^{+}$and $\mathrm{CD}^{+} \mathrm{T}$ cells from TILs stimulated with OVA. The assays were done in quadruplicates. The data shown are the representative of three experiments. ${ }^{*} p<0.05$ and ${ }^{* *} p<0.01$, ${ }^{* *} p<0.001$ and ${ }^{* * *} p<0.0001$ 


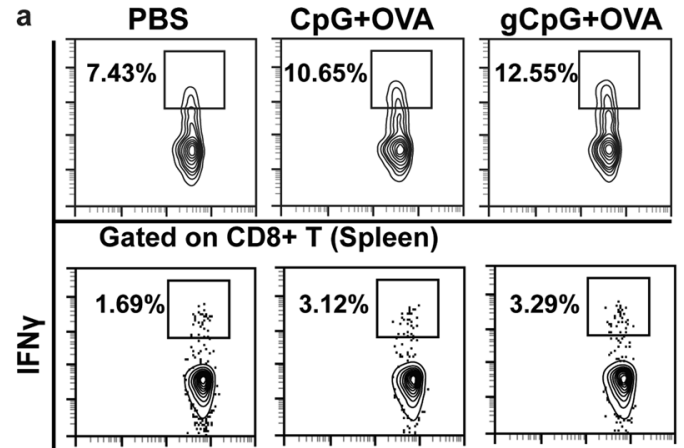

Gated on CD4+ T (Spleen)

b

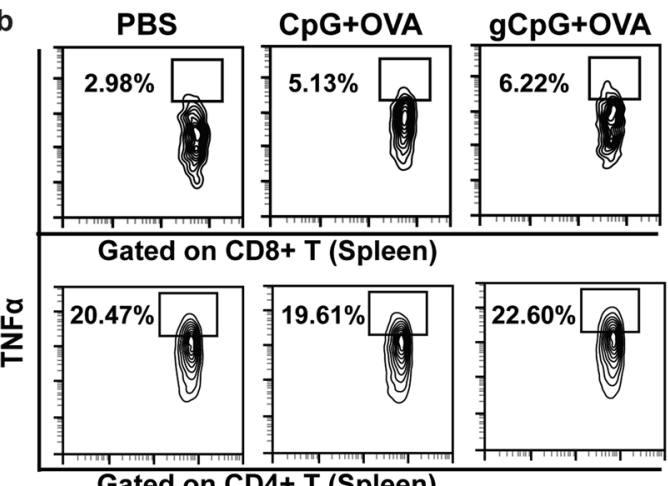

Gated on CD4+ T (Spleen)

c

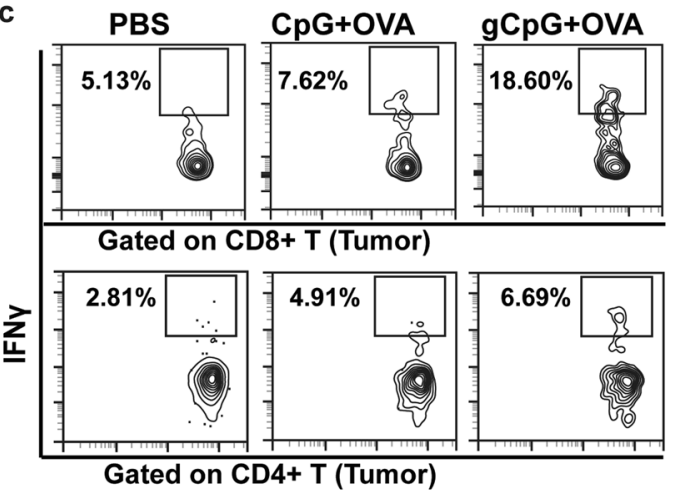

d

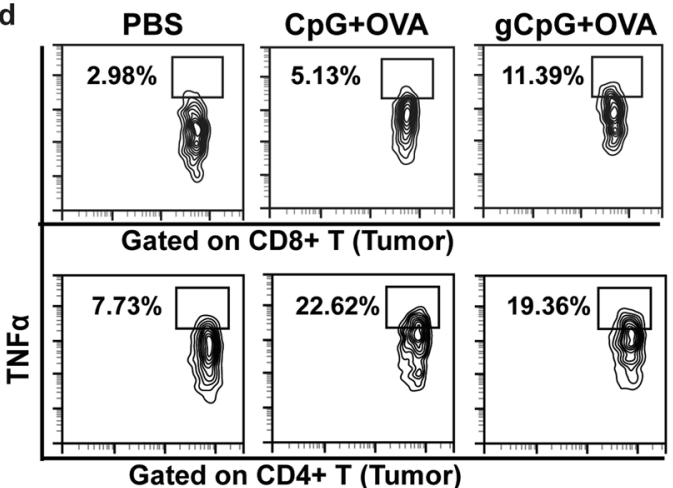

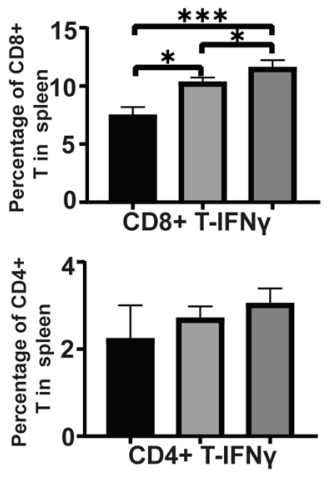
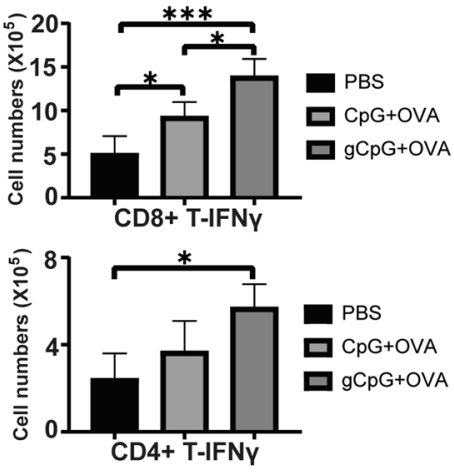

PBS

ㅁ $\mathrm{CpG}+\mathrm{OVA}$ 口 gCpG+OVA
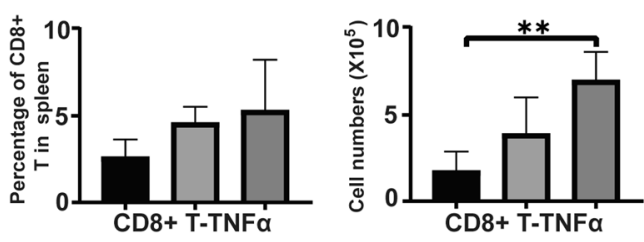

a PBS

口 $\mathrm{CpG}+\mathrm{OVA}$

口 gCpG+OVA
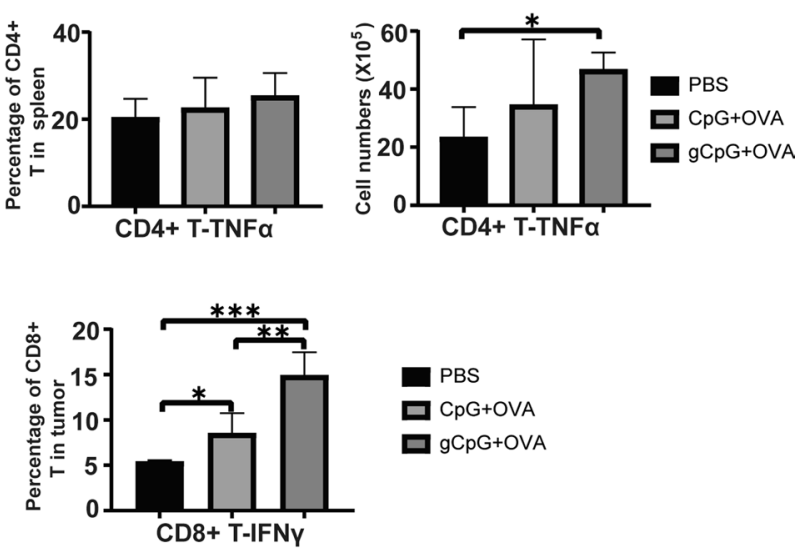

PBS

口 $\mathrm{CPG}+\mathrm{OVA}$

口 gCpG+OVA

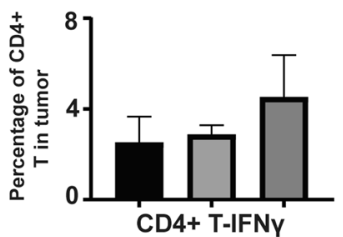

DBS

口 $\mathrm{CpG+OVA}$

口 gCpG+OVA

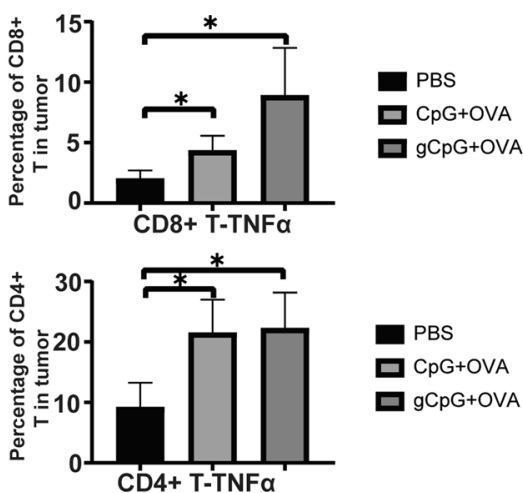

Fig. 3 (See legend on previous page.) 

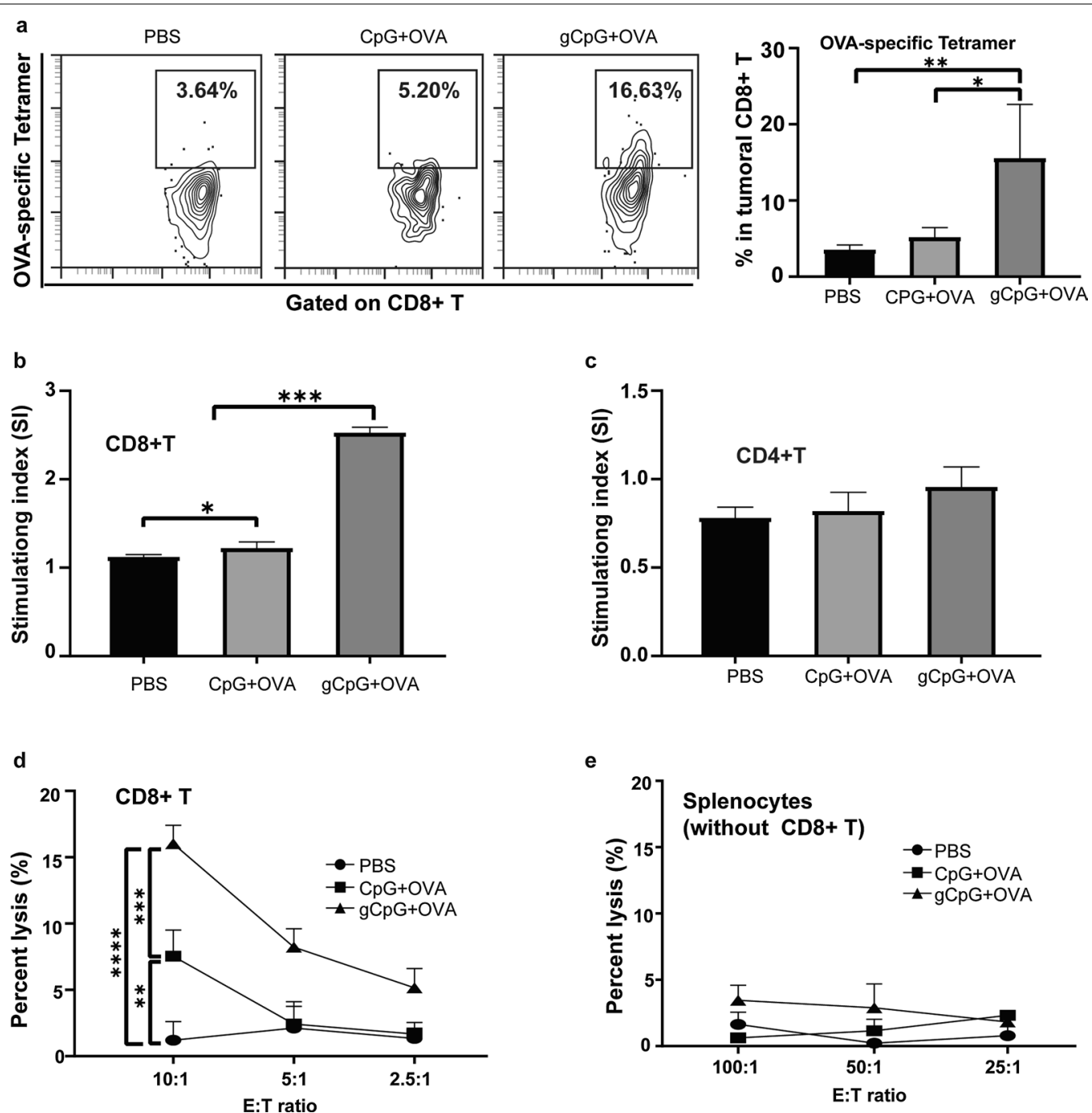

Fig. $4 \mathrm{gCpG}$ promotes antigen-specific CD8 ${ }^{+} \mathrm{T}$ cells response. a Tetramer staining of OVA-specific CD $8^{+} \mathrm{T}$ cells in TILs. Proliferations of CD4 ${ }^{+}(\mathbf{b})$ or $\mathrm{CD}^{+}$(c) T cells isolated from spleen were determined using CCK8 cell counting kits. The stimulation index (SI) is calculated as the ratio of the proliferation of cells received OVA-specific stimulation to cells without OVA-specific stimulation in the same group. Cytotoxicity assay of splenic $\mathrm{CD}^{+} \mathrm{T}$ cells $(\mathbf{d})$ and other population without $\mathrm{CD} 8^{+} \mathrm{T}$ cells (e) from the tumor-bearing mice against B16-OVA tumor cells. The specific killings were determined using CytoTox 96 nonradioactive cytotoxicity assay. ${ }^{*} p<0.05$ and ${ }^{* *} p<0.01$, ${ }^{* * *} p<0.001$ and ${ }^{* * *} p<0.0001$

of gCpG based vaccine, as the very low proportion of MDSCs infiltration in this group (Fig. 6i). These results suggested that decreasing MDSCs infiltration might play an important role in the therapeutic effects induced by gCpG + OVA treatment.

\section{Synergetic enhancement of therapeutic efficacy by gCpG combined with anti-PD1 antibody}

Programmed cell death 1 (PD1), a coinhibitory receptor expressed on activated $\mathrm{T}$ cells, can inhibit the activities of tumor-infiltrating $\mathrm{T}$ cells in TME, and thus promote tumor progress. Targeted PD1 therapies have become commonly used to enhance $\mathrm{T}$ cell responses and show efficacy in multiple cancers. gCpG + OVA treatment didn't change PD1 expression on either $\mathrm{CD}^{+}$(Fig. 7a) or $\mathrm{CD}^{+} \mathrm{T}$ cells as compared with other therapy (Fig. 7b). We wonder whether combining with anti-PD1 Ab therapy promotes the therapeutic efficacy of the gCpG included vaccine. Then, the therapeutic effect of gCpG + OVA in combination with PD1 blockade strategy was evaluated on metastasis model. gCpG + OVA vaccine in combination with antiPD1 immunotherapy exhibited a synergetic enhancement of therapeutic effects against metastasis, while anti-PD1 therapy alone could not inhibit metastasis 

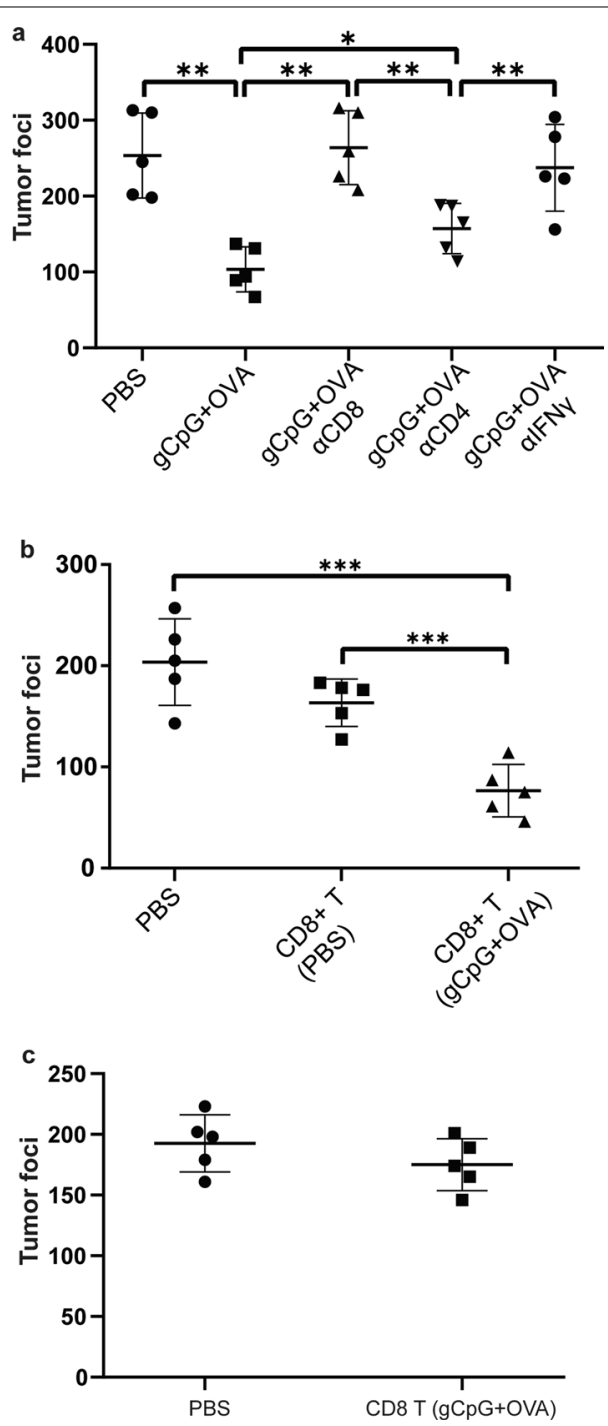

Fig. 5 Antigen-specific $C D 8^{+} T$ cells are critical for $\mathrm{gCpG}$ treatment. a Tumor foci of vaccine-treated mice were injected i.p. with $1 \mathrm{mg}$ GK1.5 (anti-mouse CD4 mAb) or 53-6.7 (anti-mouse CD8 mAb) 2 days before the first immunization, and the injections were repeated 7 days later. Mice were sacrificed on day 7 post the last immunization and the metastatic nodules were counted. $\mathbf{b} 8 \times 10^{5}$ B16-OVA were i.v. injected into each mouse from tail vein. On day $7,3 \times 10^{6} \mathrm{CD}^{+} \mathrm{T}$ cells isolated from spleen of tumor-bearing mice treated with PBS or gCpG + OVA were i.v. injected into tumor-bearing mice. Mice were sacrificed and the metastatic nodules in lung were counted 12 days later. c Mice with B16-F10 metastasis were adoptively transferred with $3 \times 10^{6} \mathrm{~T}$ cells from gCpG + OVA treated mice. Mice were sacrificed and the metastatic nodules in lung were counted 12 days later. ${ }^{*} p<0.05$ and ${ }^{* *} p<0.01,{ }^{* * *} p<0.001$ and ${ }^{* * *} p<0.0001$

(Fig. 7c), indicating the great promises of such vaccine for combination with immune checkpoint therapy.

\section{Discussion}

Cancer vaccines are designed to activate Th1 and CTL which can mediate anti-tumor immunity. To induce efficient Th1 and CTL responses, appropriate adjuvants are required to formulate with tumor antigens. $\mathrm{CpG}$ is an attractive candidate to stimulate Th1 and CTL responses, which has been widely used for vaccine formulation [20]. To enhance the effects of CpG based vaccine, we conjugated type B CpG with glucose. This new adjuvant strongly improves the therapeutic effects of tumor vaccine in both primary melanoma model and metastasis model. The adjuvant activates both tumor-specific Th1 and Tc1 responses, promotes M1 macrophages polarization and proinflammatory cytokine production, and inhibits both Treg and MDSCs in TME (Fig. 8).

CTL is essential for the eradication of cancer. gCpG treatment increased CTL populations in spleen, and enhanced specific killing of $\mathrm{CD}^{+} \mathrm{T}$ against tumor. The increased CTL infiltration has been confirmed to be correlated with better clinical outcome in many cancer types, such as melanoma, lung cancer and liver cancer [21-24]. gCpG treatment greatly enhanced antigen-specific $\mathrm{CD}^{+} \mathrm{T}$ in TME, which was consistent with the therapeutic effects of the agents. Previous studies demonstrated that $\mathrm{CpG}$ could stimulate $\mathrm{CD} 8^{+} \mathrm{T}$ response, and this effect was also confirmed in present study, as CpG+OVA treatment increased killing capacity of $\mathrm{CD}^{+} \mathrm{T}$ and promoted IFN $\gamma$-producing $\mathrm{CD}^{+} \mathrm{T}$ cells infiltration in TME. Notably, glucose modification not only greatly increased the tumor-specific killing of $\mathrm{CD}^{+}$ $\mathrm{T}$ cells, but also promoted the infiltration of TNF $\alpha$ - and IFN $\gamma$-producing $\mathrm{CD}^{+} \mathrm{T}$ cells in TEM. Although therapeutic effects of gCpG included vaccine were mainly dependent upon $\mathrm{CD}^{+} \mathrm{T}$ cells, Th cells were also important during the eradication of the tumor, as determined by in vivo depletion experiment. During activation by DCs, naive $C D 4^{+} \mathrm{T}$ cells differentiate to several effector populations, such as Th1, Th2, Th17 and Treg, according to their secretion of certain cytokines. Among them, Th1 cells, characterized by production of IFN $\gamma$ and TNF $\alpha$, can optimize CTL activity, and thus promote anti-tumor immunity [22-24]. On the contrary, Th2 and Treg populations promote cancer progression and its metastasis by suppressing Th1 activity [22-24]. gCpG included vaccine treatment greatly increased the production of TNF $\alpha$ and IFN $\gamma$ in $\mathrm{CD}^{+} \mathrm{T}$ cells, whereas the productions of IL4 and IL17 in CD4 ${ }^{+} \mathrm{T}$ cells were hard to be detected. The potential of gCpG in driving Th1-mediate immune response, which may optimize $\mathrm{CD}^{+} \mathrm{T}$ activity, makes it a promising adjuvant for cancer immunotherapy. 


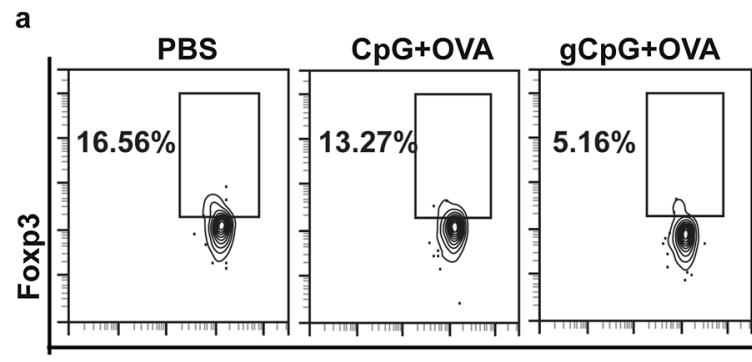

Gated on tumoral CD4+ T

C

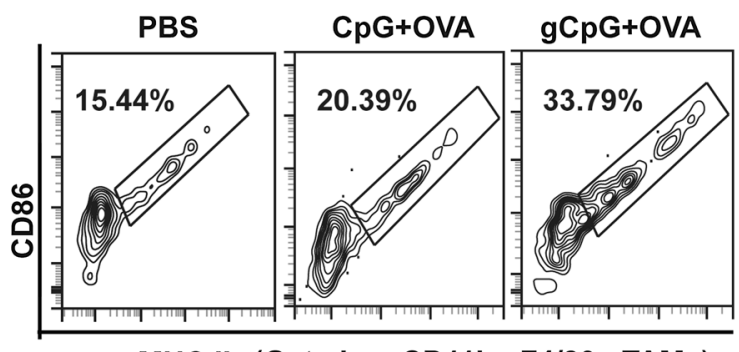

MHC II (Gated on CD11b+ F4/80+ TAMs)

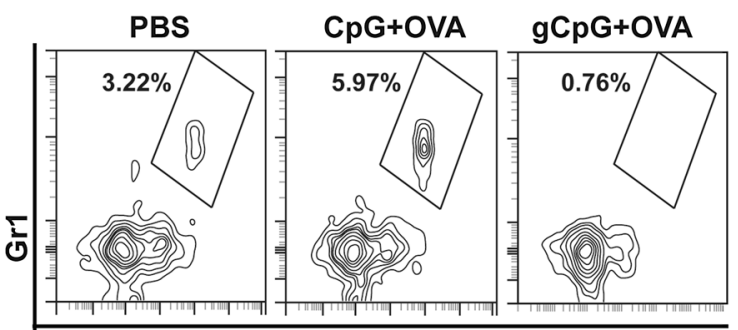

CD11b
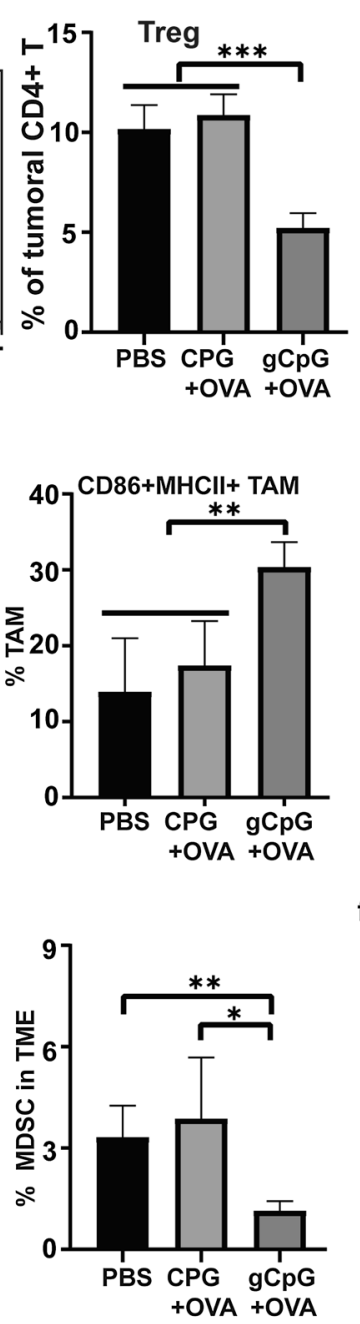

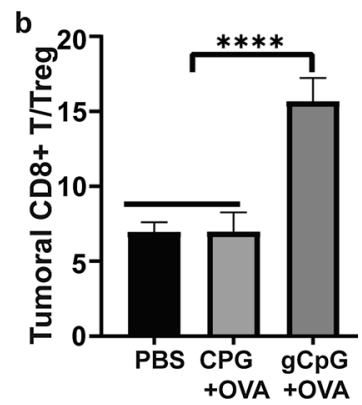

d
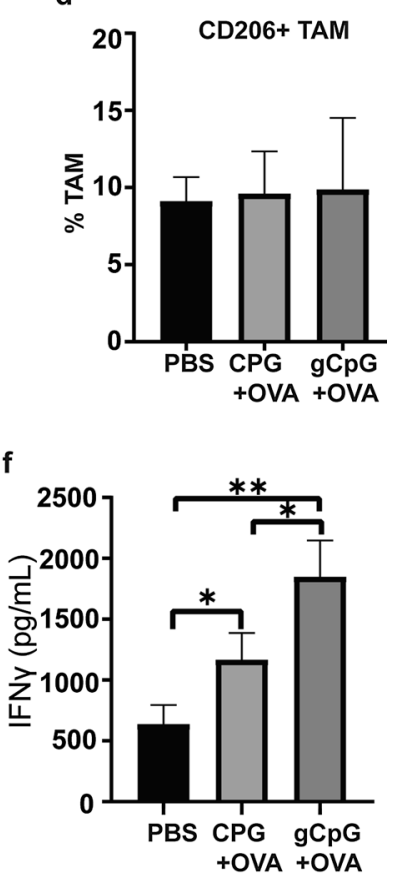

g

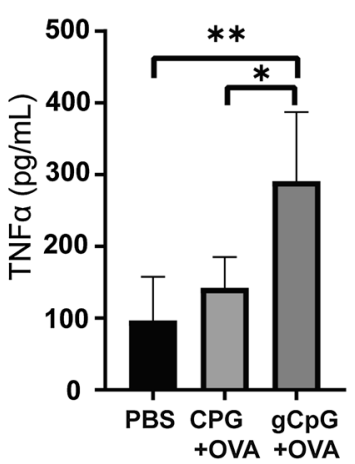

h

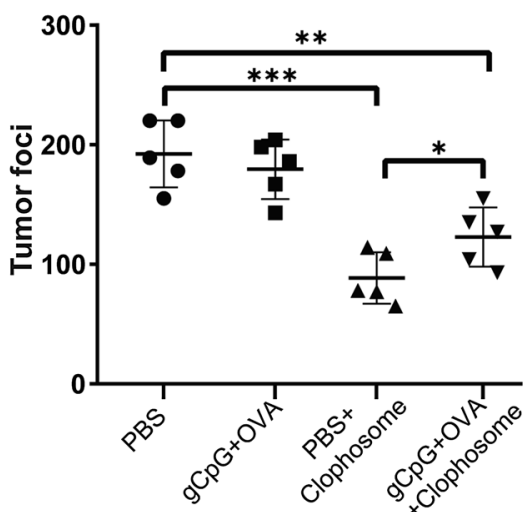

i

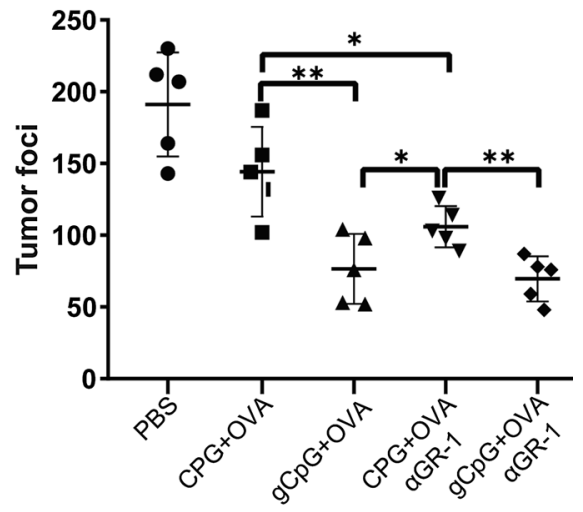

Fig. $6 \mathrm{gCpG}$ regulates tumor microenvironment. Tumor-bearing mice were immunized with PBS, CpG + OVA or gCpG on day 7 and 12 . On day 19, a frequency of Tregs, $\mathbf{b}$ CD8/Treg ratio, percentages of both M1 macrophages (c) and M2 macrophages (d), and prevalence of CD1 $1 b^{+} \mathrm{Gr} 1^{+}$ MDSC cells (e) in the TME were determined by FACS. $\mathbf{f}$ and $\mathbf{g}$ IFNY and TNFa level in supernatants of tumor. $\mathbf{h}$ and $\mathbf{i}$ Tumor foci of vaccine-treated mice with depletion of macrophages or MDSCs by i.p. injection of $800 \mu \mathrm{g}$ Clophosome or $250 \mu \mathrm{g}$ anti-Gr-1 antibody 2 day before vaccination, and the injections were repeated 7 days later. Mice were sacrificed on day 7 post the last immunization and the metastatic nodules were counted. The experiments were performed with 5-7 mice per group. The assays were done in quadruplicates. The data shown are the representative of three experiments. ${ }^{*} p<0.05$ and ${ }^{* *} p<0.01,{ }^{* * *} p<0.001$ and ${ }^{* * *} p<0.0001$ 

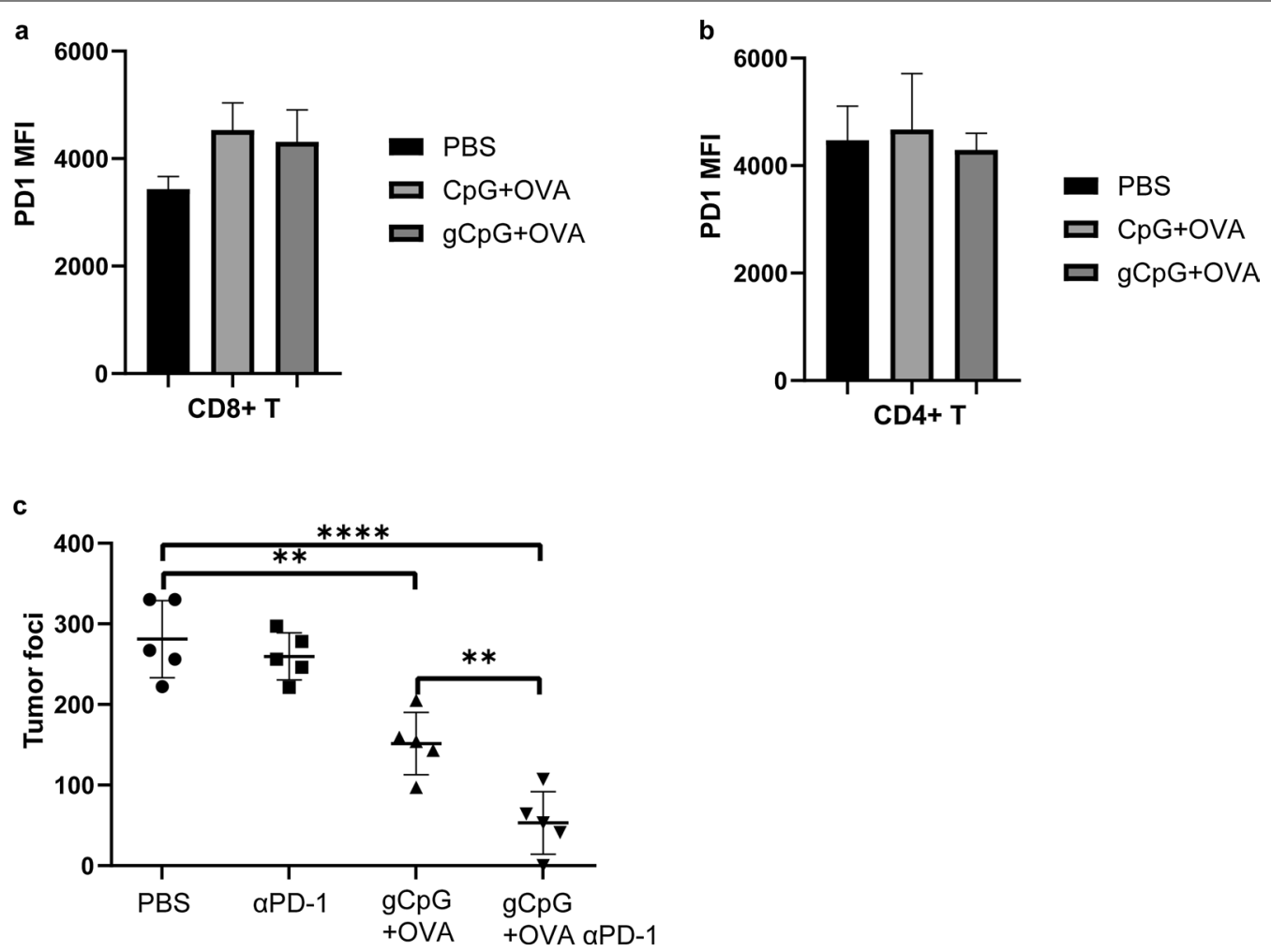

Fig. 7 Synergetic enhancement of therapeutic efficacy by gCpG combined with anti-PD1 antibody. PD1 expression (MFI) on tumor infiltrating $\mathrm{CD}^{+}(\mathbf{a})$ and $\mathrm{CD}^{+}(\mathbf{b})$ T cells. c Metastatic nodules of $2 \times 10^{6} \mathrm{~B} 16-\mathrm{OVA}$ mice treated with PBS, CpG + OVA or gCpG + OVA on day 17. On days 5 and 10, $200 \mu \mathrm{g}$ a-PD1 was administered i.p. The data shown are the representative of three experiments. ${ }^{*} p<0.05$ and ${ }^{* *} p<0.01,{ }^{* *} p<0.001$ and $* * * * p<0.0001$

Besides $\mathrm{T}$ cell priming, the desired cancer immunotherapy needs to overcome the immunosuppressive microenvironment in TME. However, expected antitumor efficacy was hard to achieve in clinical trials, as the high abundances of immunosuppressive cells presented in TME. Tregs is one of major suppressive populations in TME and many cancer vaccines exhibit the potential to promote and expand Tregs, resulting in suppression of antitumor immunity. We found that $\mathrm{gCpG}$ dramatically reduced Tregs population in TME as compared with CpG adjuvant, suggested the clinical potential of regulating Tregs in TME by gCpG. Previous studies have showed that both natural tumor progression and cancer immunotherapy outcomes in mice and humans were strongly influenced by the balance between Treg and $\mathrm{CD} 8^{+} \mathrm{T}$ cells in TME [25]. The high ratio of infiltrating $\mathrm{CD} 8^{+} \mathrm{T}$ : Tregs is often associated with prolonged survival of patient with tumor [26-28]. In present study, gCpG treatment dramatically enhanced the $\mathrm{CD} 8^{+} \mathrm{T}$ : Tregs ratio in TME, which is also consistent with the better therapeutic effects in metastasis model.
Macrophages play a crucial role in host defense against pathogens and in defense against tumor cells also. Macrophages can be divided into M1 and M2 in TME. It has been well documented that M1 functions in antigenpresenting activity and mediate cytotoxic functions, including anticancer activity [29]. On the contrary, M2 macrophages promote the development of tumor, and their occurrences in TME is highly correlated with poor prognosis of tumor [30]. Previous study showed that glucose upregulated CD86 expression on DC [16]. Here, we found that $\mathrm{gCpG}$ could promote upregulation of both CD86 and MHC II on macrophages, but the CD206 expression was not affected, suggested gCpG treatment promoted TAMs polarization toward M1 phenotype. Given the high percentage of M1 macrophages in TME and potentiating antitumor immunity of these populations, it is presumed that polarization of macrophages toward M1 in TME by gCpG plays a role in its immunotherapeutic effects on tumors. Then, depletion of macrophages in gCpG-treated mice exhibited significant progress of tumor metastasis, confirmed M1 role 


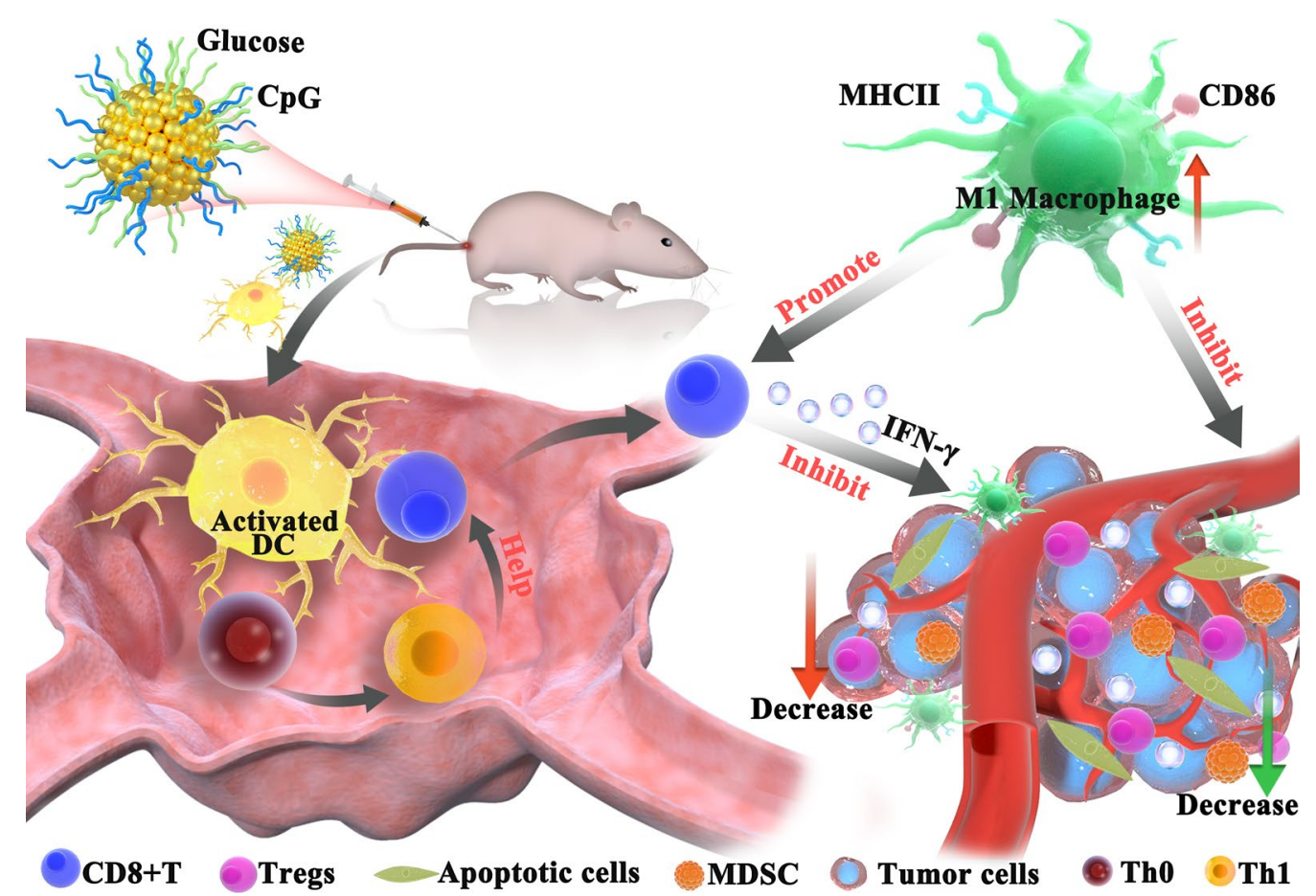

Fig. 8 Model of gCpG action. gCpG included tumor vaccine promotes DC maturation to activate tumor-specific Th and CD8 $8^{+} T$ cells. IFN- $\gamma$ producing $\mathrm{CD} 8^{+} \mathrm{T}$ cells infiltrated the tumor. TME is also regulated by the vaccine through promoting $\mathrm{M} 1$ macrophage and decreasing the prevalence of Tregs and MDSCs, which promots anti-tumor immunity

in controlling metastasis by gCpG. Inhibition the function of MDSCs is one of important strategies for cancer immuno-therapy [31-33]. gCpG dramatically reduced MDSCs accumulation in TME, indicated that decreasing of MDSC in TME by gCpG may play a role in its immunotherapeutic effects on tumors. Depletion of MDSC had no obvious effects in gCpG-treated mice with low prevalence of MDSCs infiltration. However, therapeutic efficacy was significantly enhanced in CpG-treated mice with high prevalence of MDSCs in TME, suggested the important role of reduction MDSCs infiltration by gCpG treatment in controlling tumor metastasis.

PD1 is one of key inhibitory molecules expressed on $\mathrm{T}$ cells $[34,35]$. Anti-PD1 treatment alone has no obviously therapeutic effects against tumor growth, and the main reason may be the rare $\mathrm{CD}^{+} \mathrm{T}$ infiltration in tumor, especially the lack of antigen-specific $\mathrm{CD}^{+} \mathrm{T}$. On the control, gCpG based tumor vaccine treatment dramatically enhanced tumor-infiltrating $\mathrm{CD}^{+} \mathrm{T}$, especially antigen-specific $\mathrm{CD}^{+} \mathrm{T}$, and the combination of anti-PD1 treatment and gCpG based tumor vaccine thus dramatically enhanced the therapeutic efficacy of tumor growth.

\section{Conclusion}

In present study, we chemically conjugated type B CpG with glucose and obtained a new CpG adjuvant. This adjuvant activated Th1 and Tc1, enhanced tumor-specific CTL responses and regulated TME through promoting M1 macrophages polarization and inhibiting both Treg and MDSCs.

\section{Abbreviations}

APC: Antigen-presenting cell; DC: Dendritic cell; PRR: Pattern recognition receptor; ODN: Synthetic oligodeoxynucleotide; Th: T helper cell; Tc: Cytotoxic T cell; NK: Nature killer; MDSC: Meyloid-derived suppressor cell; OVA: Ovalbumin; MHC: Major histocompatibility complex; TME: Tumor microenvironments; TAM: Tumor associated macrophage; Treg: Regulatory T cells; PD-1: Program death-1; IFN: Interferon.

\section{Acknowledgements}

We thank the laboratory members for reagents and assistance with experiments.

\section{Authors' contributions}

$X X, Y G$ and $C Y$ performed the substantial experiments and drafted the manuscript. TF, ML and CW analyzed the data and drew the figures. $X C$ revised the manuscript. JZ,WZ and LZ supervised the experiments. XX and LZ got the grant and designed the project. All authors read and approved the final manuscript. 


\section{Funding}

This work was supported by the National Natural Science Foundation of China (31870918, 22171202 and 31500746), Natural Science Fund of Jiangsu Province (BK20170334), Open Project Program of Jiangsu Key Laboratory of Zoonosis (R1906) and Project Funded by the Priority Academic Program Development of Jiangsu Higher Education Institutions.

\section{Availability of data and materials}

All data and materials in this study are included in the published article and its additional file.

\section{Declarations}

\section{Ethics approval and consent to participate}

All animal experiments were approved by the Animal Ethics Committee of Soochow University.

\section{Consent for publication}

All authors in the paper agree to be published.

\section{Competing interests}

The authors declare that they have no competing interests.

\section{Author details}

${ }^{1}$ College of Basic Medicine and Biological Sciences, Medical Department, Soochow University, 215123 Suzhou, People's Republic of China. ${ }^{2}$ Department of Orthopaedic Surgery, The First Affiliated Hospital of Soochow University, Suzhou 215006, Jiangsu, China. ${ }^{3}$ Institute of Blood and Marrow Transplantation, Department of Hematology, Collaborative Innovation Center of Hematology, The First Affiliated Hospital of Soochow University, Suzhou, People's Republic of China. ${ }^{4}$ Center for Soft Condensed Matter Physics and Interdisciplinary Research, Soochow University, Suzhou 215006, People's Republic of China. ${ }^{5}$ Jiangsu Key Lab of Zoonosis/Jiangsu Co-Innovation Center for Prevention and Control of Important Animal Infectious Diseases and Zoonoses, Yangzhou University, Yangzhou, China.

Received: 24 September 2021 Accepted: 8 November 2021

Published online: 18 November 2021

\section{References}

1. Duinkerken S, Horrevorts SK, Kalay H, Ambrosini M, Rutte L, de Gruijl TD, et al. Glyco-dendrimers as intradermal anti-tumor vaccine targeting multiple skin DC subsets. Theranostics. 2019;9(20):5797-809.

2. Xu X, Jin Z, Liu Y, Gong H, Sun Q, Zhang W, et al. Carbohydrate-based adjuvants activate tumor-specific Th1 and $C D 8^{+}$T-cell responses and reduce the immunosuppressive activity of MDSCs. Cancer Lett. 2019;440-441:94-105.

3. Huang Z, Wei G, Zeng Z, Huang Y, Huang L, Shen Y, et al. Enhanced cancer therapy through synergetic photodynamic/immune checkpoint blockade mediated by a liposomal conjugate comprised of porphyrin and IDO inhibitor. Theranostics. 2019;9(19):5542-57.

4. Kumai T, Lee $\mathrm{S}, \mathrm{Cho} H \mathrm{HI}$, Sultan H, Kobayashi H, Harabuchi Y, et al. Optimization of peptide vaccines to induce robust antitumor CD4 T-cell responses. Cancer Immunol Res. 2017;5(1):72-83.

5. Ohto U, Ishida H, Shibata T, Sato R, Miyake K, Shimizu K. Toll-like receptor 9 contains two DNA binding sites that function cooperatively to rromote receptor dimerization and activation. Immunity. 2018;48(4):649-58.

6. Lai C, Duan S, Ye F, Hou X, Li X, Zhao J, et al. The enhanced antitumor-specific immune response with mannose- and CPG-ODN-coated liposomes delivering TRP2 peptide. Theranostics. 2018;8(6):1723-39.

7. Maynard SK, Marshall JD, MacGill RS, Yu L, Cann JA, Cheng LI, et al. Vaccination with synthetic long peptide formulated with CpG in an oil-inwater emulsion induces robust E7-specific CD8 T cell responses and TC-1 tumor eradication. BMC Cancer. 2019;19(1):540.

8. Pradhan P, Qin H, Leleux JA, Gwak D, Sakamaki I, Kwak LW, et al. The effect of combined ILI0 siRNA and CPG ODN as pathogen-mimicking microparticles on Th1/Th2 cytokine balance in dendritic cells and protective immunity against B cell lymphoma. Biomaterials. 2014;35(21):5491-504.
9. Shirota $\mathrm{H}$, Klinman DM. TLR-9 agonist immunostimulatory sequence adjuvants linked to cancer antigens. Methods Mol Biol. 2014;1139:337-44.

10. Miles SA, Sandler AD. CpG oligonucleotides for immunotherapeutic treatment of neuroblastoma. Adv Drug Deliv Rev. 2009;61(3):275-82.

11. Shirota $H$, Tross D, Klinman DM. CpG oligonucleotides as cancer vaccine adjuvants. Vaccines. 2015;3(2):390-407.

12. Grees M, Sharbi-Yunger A, Evangelou C, Baumann D, Cafri G, Tzehoval E, et al. Optimized dendritic cell vaccination induces potent CD8 T cell responses and anti-tumor effects in transgenic mouse melanoma models. Oncoimmunology. 2018;7(7): e1445457.

13. Yuan Y, Long L, Liu J, Lin Y, Peng C, Tang Y, et al. The double-edged sword effect of macrophage targeting delivery system in different macrophage subsets related diseases. J Nanobiotechnol. 2020;18(1):168.

14. van Dinther D, Stolk DA, van de Ven R, van Kooyk Y, de Gruijl TD, den Haan JMM. Targeting C-type lectin receptors: a high-carbohydrate diet for dendritic cells to improve cancer vaccines. J Leukoc Biol. 2017;102(4):1017-34.

15. Maglinao M, Eriksson M, Schlegel MK, Zimmermann S, Johannssen T, Gotze S, et al. A platform to screen for C-type lectin receptor-binding carbohydrates and their potential for cell-specific targeting and immune modulation. J Control Release. 2014;175:36-42.

16. Lu H, Yao K, Huang D, Sun A, Qian J, Ge J. High glucose induces upregulation of scavenger receptors and promotes maturation of dendritic cells. Cardiovasc Diabetol. 2013:12:80.

17. Ho PC, Bihuniak JD, Macintyre AN, Staron M, Liu X, Amezquita R, Tsui YC, et al. Phosphoenolpyruvate is a metabolic checkpoint of anti-tumor $T$ cell responses. Cell. 2015;162(6):1217-28.

18. Wen M, Liu M, Xue W, Yang K, Chen G, Zhang W. Simple and green strategy for the synthesis of "pathogen-mimetic" glycoadjuvant@AuNPs by combination of photoinduced RAFT and bioinspired dopamine chemistry. ACS Macro Lett. 2018;7:70-4.

19. Vedhara K, Ayling K, Sunger K, Caldwell DM, Halliday V, Fairclough L, et al. Psychological interventions as vaccine adjuvants: a systematic review. Vaccines. 2019;37(25):3255-66.

20. Zhang J, Zhao T, Han F, Hu Y, Li Y. Photothermal and gene therapy combined with immunotherapy to gastric cancer by the gold nanoshellbased system. J Nanobiotechnol. 2019;17(1):80.

21. Buzzonetti A, Fossati M, Catzola V, Scambia G, Fattorossi A, Battaglia A, et al. Immunological response induced by abagovomab as a maintenance therapy in patients with epithelial ovarian cancer: relationship with survival-a substudy of the MIMOSA trial. Cancer Immunol Immunother. 2014;63(10):1037-45

22. Odunsi K, Matsuzaki J, James SR, Mhawech-Fauceglia P, Tsuji T, Miller A, et al. Epigenetic potentiation of NY-ESO-1 vaccine therapy in human ovarian cancer. Cancer Immunol Res. 2014;2(1):37-49.

23. Gandhapudi SK, Ward M, Bush JPC, Bedu-Addo F, Conn G, Woodward JG, et al. Antigen priming with enantiospecific cationic lipid nanoparticles induces potent antitumor CTL responses through novel induction of a type I IFN response. J Immunol. 2019;202(12):3524-36.

24. Elia AR, Grioni M, Basso V, Curnis F, Freschi M, Corti A, Mondino A, et al. Targeting tumor vasculature with TNF leads effector T cells to the tumor and enhances therapeutic efficacy of immune checkpoint blockers in combination with adoptive cell therapy. Clin Cancer Res. 2018;24(9):2171-81.

25. Zhou G, Drake CG, Levitsky HI. Amplification of tumor-specific regulatory T cells following therapeutic cancer vaccines. Blood. 2006;107(2):628-36.

26. Sato E, Olson SH, Ahn J, Bundy B, Nishikawa H, Qian F, et al. Intraepithelial $\mathrm{CD}^{+}$tumor-infiltrating lymphocytes and a high $\mathrm{CD}^{+} /$regulatory $T$ cell ratio are associated with favorable prognosis in ovarian cancer. Proc Natl Acad Sci U S A. 2005;102(51):18538-43.

27. Bui JD. Comparative analysis of regulatory and effector T cells in progressively growing versus rejecting tumors of similar origins. Cancer Res. 2006;66(14):7301-9.

28. Gao Q, Qiu SJ, Fan J, Zhou J, Wang XY, Xiao YS, et al. Intratumoral balance of regulatory and cytotoxic $T$ cells is associated with prognosis of hepatocellular carcinoma after resection. J Clin Oncol. 2007;25(18):2586-93.

29. Cheng H, Wang Z, Fu L, Xu T. Macrophage polarization in the development and progression of ovarian cancers: an overview. Front Oncol. 2019;9:421. 
30. Evrard D, Szturz P, Tijeras-Raballand A, Astorgues-Xerri L, Abitbol C, Paradis $V$, et al. Macrophages in the microenvironment of head and neck cancer: potential targets for cancer therapy. Oral Oncol. 2019;88:29-38.

31. Li A, Barsoumian HB, Schoenhals JE, Cushman TR, Caetano MS, Wang X, et al. Indoleamine 2,3-dioxygenase 1 inhibition targets anti-PD1-resistant lung tumors by blocking myeloid-derived suppressor cells. Cancer Lett. 2018;431:54-63.

32. Zhang H, Li ZL, Ye SB, Ouyang LY, Chen YS, He J, et al. Myeloid-derived suppressor cells inhibit T cell proliferation in human extranodal NK/T cell lymphoma: a novel prognostic indicator. Cancer Immunol Immunother. 2015;64(12):1587-99.

33. Zhan $X$, Fang $Y$, Hu S, Wu Y, Yang $K$, Liao $C$, et al. IFN- $\gamma$ differentially regulates subsets of $\mathrm{Gr}-1(+) \mathrm{CD} 11 \mathrm{~b}(+)$ myeloid cells in chronic inflammation. Mol Immunol. 2015;66(2):451-62.
34. Kollmann D, Schweiger T, Schwarz S, Ignatova D, Chang YT, Lewik G, et al. PD1-positive tumor-infiltrating lymphocytes are associated with poor clinical outcome after pulmonary metastasectomy for colorectal cancer. Oncoimmunology. 2017;6(9): e1331194.

35. Ma L, Zhu M, Gai J, Li G, Chang Q, Qiao P, et al. Preclinical development of a novel CD47 nanobody with less toxicity and enhanced anti-cancer therapeutic potential. J Nanobiotechnology. 2020;18(1):12.

\section{Publisher's Note}

Springer Nature remains neutral with regard to jurisdictional claims in published maps and institutional affiliations.
Ready to submit your research? Choose BMC and benefit from:

- fast, convenient online submission

- thorough peer review by experienced researchers in your field

- rapid publication on acceptance

- support for research data, including large and complex data types

- gold Open Access which fosters wider collaboration and increased citations

- maximum visibility for your research: over $100 \mathrm{M}$ website views per year

At BMC, research is always in progress.

Learn more biomedcentral.com/submissions 